\title{
The changes of sustainable primary school buildings
}

\author{
S. Gölemen, N. Taş \& M. Taş \\ Department of Architecture, Faculty of Architecture, \\ Uludăg University, Turkey
}

\begin{abstract}
Recently, there has been a sustainability movement in both currently built and existing structures in many cities around the world. One of these structures is the school buildings where new generations are educated. In Turkey, there are quality problems in built school buildings in terms of sustainable architecture principles for the residents and the environment. In addition, environmental, economic and social losses occur unless sustainable precautions are taken in such buildings. It is proposed that, as a model for the sustainability movement, every primary school in cities be designed within these principles so that new generations can grow up and receive education in a sustainable environment and their parents can become aware of this issue. This study particularly examines the existing primary school buildings that were built with a typical project principle. In order to raise the living standards of children and also for environmental sustainability, the existing conditions of the school buildings should be improved and transformed in a sustainable way. In this context, the study is restricted to two scopes: existing primary schools in Turkey and sustainability in existing buildings. As a method, a primary school which was built with a typical project in a developing district was evaluated within the framework of sustainability principles. In addition, improvement and recovery through sustainability integration as a concept were proposed. Application of this approach can be regarded as an important step in terms of sustainable transformation in cities starting from local district schools to other local residential buildings and other buildings as well. It is believed that this approach holds an important role in creating sustainability awareness and integration in a national and global aspect.
\end{abstract}

Keywords: sustainability, sustainable integration, adapted reuse, existing primary schools, Turkey, Bursa. 


\section{Introduction}

The term "sustainability" essentially refers to "continuity". The aim of sustainability is to provide the continuity of the existing structures that have fulfilled their function and/or existence up to the present as well as the production of what is desired. The aim of sustainability in terms of architecture is not only construction of ecological buildings but it is also the effective provision of sustainability of present ones as well. Existing buildings should be evaluated not only as structures occupying land but also as entities having time, materials, energy and economic investments values. In this sense, it is not sensible to demolish all buildings and reconstruct them. Instead, the buildings need sustainable changes [1].

Revaluation of existing buildings in a sustainable way is only viewed only from a physical aspect (structural, technological, environmental and ecological) but sustainability should be evaluated in terms of socio-economic context if it is desired to be attained in real sense. In order for primary schools to be evaluated holistically, besides physical factors it is important take into consideration of all factors including psychological, perceptual, ideological, socio-cultural, historical, geographical, political and ecological.

In this study, development of primary state schools in Turkey has been evaluated within historical, economic, and legal framework. A field study was carried out by selecting a sample primary school that was built in recent past by this system in Turkey. For the sustainable changes of the school, which is in Nilüfer District, Bursa, principle decisions have been put forward. These principle decisions have been illustrated the plan, facades and sections of the existing building schematically [2].

\section{Sustainability of existing buildings}

Many international studies which have taken place recently emphasise sustainability with target applications and updates from the local to the global aspects (Table 1).

Sustainability consists of three dimensions namely physical, social and economic. Physical dimension is directly related to build environment and architecture. Architecture reflects to the physical area by means of buildings and thus correlates with environment directly. These buildings should comply with the environment to provide the best conditions for humans to continue their life in a healthy way. In this sense, sustainability of buildings and construction can contribute to sustainable architecture within physical scale [4].

Sustainable architecture requires transformation of existing buildings into "sustainable buildings" along with the construction of new buildings in a way to provide their residents with a qualified interior design and with efficient consumption of water, energy and resource at the construction stage. Sustainable transformation includes all processes that are realized to improve interior quality of the place, to reduce water use, to improve environmental performance, and to improve energy efficiency of a building thoroughly or partially [8] (Figure 1). 
Table 1: Historical development of sustainability and sustainable growth.

\begin{tabular}{|c|c|}
\hline 1972 & Club of Rome - Limits to Growth \\
\hline & $\begin{array}{l}\text { Sweden - The United Nations Conference on the Human } \\
\text { Environment }\end{array}$ \\
\hline & $\begin{array}{l}\text { Vancouver - The United Nations Centre for } \\
\text { Human Settlements - Habitat I }\end{array}$ \\
\hline & $\begin{array}{l}\text { United Nations Environment Programme - (UNEP) } \\
\text { The World Conservation strategy - (WCS) }\end{array}$ \\
\hline & $\begin{array}{l}\text { Our Common Future - United Nations World } \\
\text { Commission on Environment and Development (WCED) }\end{array}$ \\
\hline & $\begin{array}{l}\text { Rio de Janeiro - Earth Summit - United Nations World } \\
\text { Commission on Environment and Development (WCED) }\end{array}$ \\
\hline & The Commission on Sustainable Development - (CSD) \\
\hline & $\begin{array}{l}\text { Cairo - International Conference on Population and } \\
\text { Development (ICPD) }\end{array}$ \\
\hline & $\begin{array}{l}\text { Copenhagen - World Summit for Social Development and } \\
\text { Beijing - Fourth World Conference on Women }\end{array}$ \\
\hline & $\begin{array}{l}\text { İstanbul - The United Nations Centre for } \\
\text { Human Settlements - Habitat II }\end{array}$ \\
\hline & New York - (Rio+5) and Kyoto Protocol \\
\hline & Turkey - Law for Heat Insulation in Buildings (TS825) \\
\hline & New York - Millennium Summit (UN) \\
\hline & $\begin{array}{l}\text { Johannesburg - World Summit on Sustainable } \\
\text { Development }(\text { Rio }+10)\end{array}$ \\
\hline & Turkey - Energy Efficiency Law no.5627 \\
\hline & Turkey - Turkish Green Building Council (CCEDBİK) \\
\hline & $\begin{array}{l}\text { Rio de Janeiro - World Summit on Sustainable } \\
\text { Development (Rio+20) }\end{array}$ \\
\hline
\end{tabular}

Sustainable building approach includes all the processes beginning from the design of the construction till its demolishment. But sustainability implementation can be done either during the stage of usage and maintenance or by means of reusing some parts. 


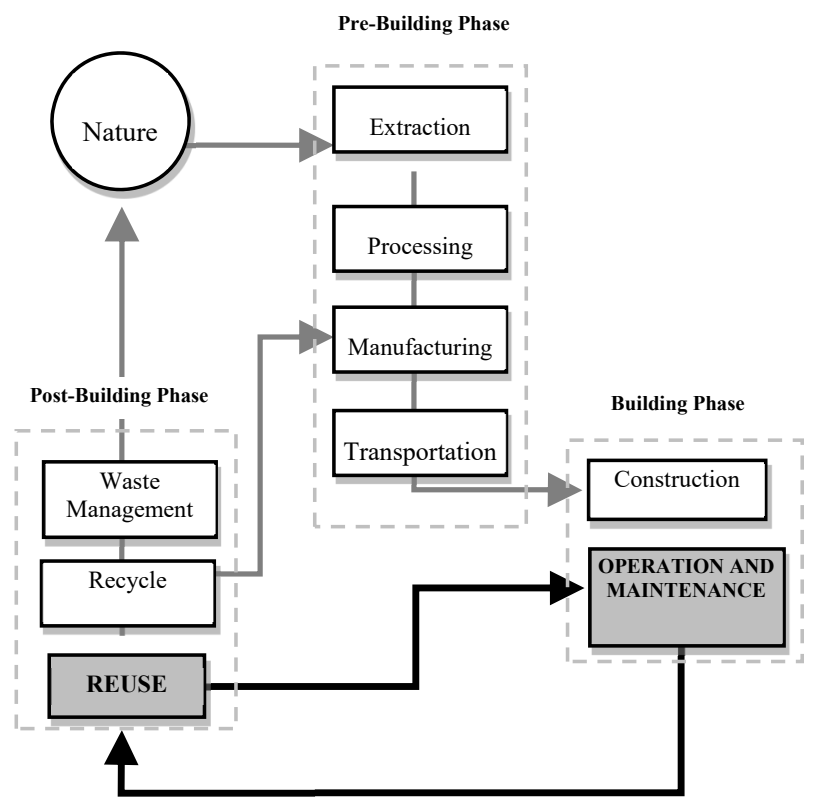

Figure 1: The sustainability steps of building life cycle in existing buildings.

\subsection{Sustainability of existing primary schools}

Primary aims of sustainable improvement of existing school buildings can be classified in three categories within the framework of sustainability [9]:

\section{Physical aims}

- Protection of resources;

- Land;

- Energy;

- Water;

- Material.

\section{Social aims}

- Multidisciplinary and integrated work by participation of the user;

- Implementations of designs to teach sustainability;

- Development of academic performance of the users;

- Support for social values;

- Realization of comfortable, healthy, and safe designs.

\section{Economic aims}

- Evaluation of already existing investments by means of extending the functional lifespan of buildings;

- Reduction of operational costs during occupancy of the buildings to minimum level. 
Certain estimated criteria such as location in the land, azimuth and its amount, structure etc. estimated in existing buildings may not be changed afterwards. Physical interventions such as taking under control, repairmen, improvement, and reduction can be implemented to these unchangeable criteria. Both sustainable design approach and sustainability in existing buildings aim to attend the same goals in environmental, social and economic sense.

Following criteria should be taken into consideration and a feasibility work should be carried out when an existing building is determined to be reused [8]:

- Conservation of form, function, and structure;

- Conservation of the original plan, sections, and façade;

- Conservation of characteristic properties of the buildings and provision of the use of integrated outbuildings with the original building;

- Harmony of the newly constructed function attached to the building with the social and physical environment;

- The building's economic life not being completed.

Along with these principles, another recent issue to consider in Turkey is the reality of earthquake. $42 \%$ of Turkey's surface area is on first-degree seismic zone [10]. School buildings have crucial importance as children and young adults receive education there and are designated for people to gather after earthquakes as temporary shelters. For this reason, existing school buildings which are suitable in terms of bearing capacity should be determined and their building lifespan should be evaluated. Besides, economic and schedule feasibility with respect to repair should be done. Based on the data gathered estimated sustainable changes should be planned and implemented [11].

\subsubsection{Physical factors}

The main physical factor in the existing buildings is "land use" that has been planned and implemented beforehand. After the construction of the building if unchangeable location and direction of the building affects the structure negatively, a set of different precautions need to be taken for light control or natural illumination. Unless there is space in the facade to get enough light, embrasures could be changed or sunlight could be let into the classrooms by placing light shelves. Photovoltaic panels or sunshades could be utilized for the light control in south or west facade. Energy-efficient and sensor-fitted lamps should be placed in interior halls that receive no direct sunlight. The energy required should be maintained by solar panels [12].

Second important factor is structural properties of the building. Especially in case of earthquake it is not desirable for the building to pose a threat for the residents. Therefore, prior to dwelling earthquake safety tests of the building need to be done primarily for the residents' safety. Besides, since structural design and construction technique are irreversible, schematic modifications such as wall partitions could be done.

Another important factor is "conservation of heat energy". For this, the structural shell of the existing building should be insulated according to the climate region. A recently implemented method is circulation of the stable heat and the greenhouse effect of the sun in the house through culverts. This heat pump system 
can also be used reversibly to cool the building. It would be sensible to support these systems with HVAC systems. The required energy can be sustained from solar energy generating electricity through active [12].

Along with these factors, in order to maintain "water saving", low-flow taps that have censor should be used. Double toilet flush tank system should be placed and waste water should be reused in the reservoirs thus clean water consumption is reduced. A tank for collecting rain water should be installed for clean water conservation. Main restriction for this is the adaptation of the installation. Suitable space should be created for the affixed pipes. Besides, the installation system should be integrated properly for future interventions [13].

Required materials for creating "comfortable interior conditions" (thermal, visual, audial, psychological) should be replaced with healthier and more suitable ones. Floorings should be implemented with nontoxic and easily vaporizable materials like VOC. For acoustic control of interior places, prefabricated panels should be utilized. The colour of the places should be used and designed tin a creative and educative way for the residents to benefit.

All these applications are to be evaluated and implemented holistically. While holistic approach can be planned beforehand for newly-built constructions, it is quite difficult to provide the integration of different systems in existing buildings. Constant changes in technological developments need to be followed.

The environmental data of the existing building make it hard for the future interventions. Sun's angel of incidence, seasonal angel and direction, gale force, the height of the surrounding buildings, frequency of vehicles on the roads, noise problem, pedestrians, green spaces, and rivers etc. all constitute environmental and ecologic factors. Environmental and ecologic data should be taken into consideration both in design and implementation stages.

\subsubsection{Social and economic factors}

According to statistics of TUIK (Turkish Statistical Institute) there are 44.513 primary schools in Turkey [14]. Sustainability of these existing buildings would be of great benefit to the country in terms of both economic and social aspect. Extending the lifespan of present buildings and investments via renewal work will help maintain economic sustainability in broader sense. By conserving water and energy considerably, country's resources can be preserved. By means of this approach, awareness for sustainability in social aspect could be attained starting from local scale extending to regional even global scale. And this awareness could be of great benefit for sustainable growth and welfare. The benefits in social dimension have been stated as following [2]:

- Benefits for the individual: Focusing on the student, developing individual awareness, integration of lessons with real life, experiencing in the environment;

- Benefits for the society: Creating awareness of sustainability, developing environmental projects for students;

- Benefits for the government: strengthening democratic principles, helping citizens to become participating actors, integrating action with politics. 
Existing school buildings may undertake the mission of introducing, initiating and spreading of sustainability throughout the country. By sustainable change of these existing buildings, sustainable growth can be attained with the help of individuals on a local scale, society on a regional scale, and the government on a global scale. In this sense, it is strategically aimed to raise awareness of sustainability throughout the country starting from the individual level.

\section{A case study: sustainability approach in an existing primary school building in Turkey}

Since the establishment of the Turkish Republic in 1923, there have been various legislations, practices, and implementations to improve the quality of education in Turkey. As a result, the level of literacy has risen up sharply.

In our country, typical projects for school buildings have been practiced for years due to the difficulties in terms of preparing different project in different regions, lack of time, worker, and finance. Besides there are other difficulties e.g. it is hard for local administrations and private entrepreneurs to reconcile. Public procurement law, time-consuming bureaucratic procedures and other implements may also cause loss of time and money [15]. As a result of these above-mentioned difficulties, mostly typical projects are commonly implemented instead of original ones that are rarely preferred. The school building selected for this case study is one of the typical projects.

The building analysed in the study is in Bursa city which has received a great amount of migration since the republic period started. It is a developing city. The district of the school building, Nilüfer, is a fast developing district for over fifteen years (Figure 2).
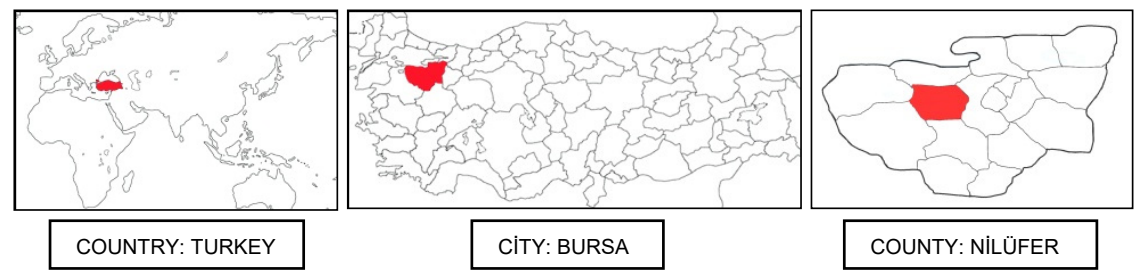

Figure 2: The localization of the case study.

The case study was carried out in Bursa, Turkey. The selected school, Abdurrahman Vardar Primary State School, is located in a fast growing district named Nilüfer of Bursa city. The school was built in 2004. There are typical (L-shaped) primary school and a kindergarten (1), an indoor sports hall (2), an outdoor sports area (3), a playground (4), a canteen (5), a separate kindergarten building (6) and a car park (7). There are 1800 students, 79 teachers, and 6 administrates in the school where primary and secondary students receive education either starting from the morning till the afternoon or from the afternoon till the evening [2] (Figure 3).

In the case study, the primary school building is investigated according to physical aims that are protection of resources, land, energy, water and material. 


\subsection{Protection of resources}

In this study, the main purpose is protection of resources. Existing buildings which built lately and others, both of them contain used material, used energy, given labour and spent time. Especially existing building built lately is worth to make sustainable to prolong building life and quality.

\subsection{Land}

Students reach to the primary school on food and by school buses. However, at the neighbourhood level vehicle priority should be given to the use of bicycles instead of school buses. Therefore, schools should be around traffic measures in some ways and bicycle which is established in the neighbourhood. In addition, the primary school has a playground which is an asphalt pavement. It is necessary to supply green for children to grow up and learn in nature (Figure 4).
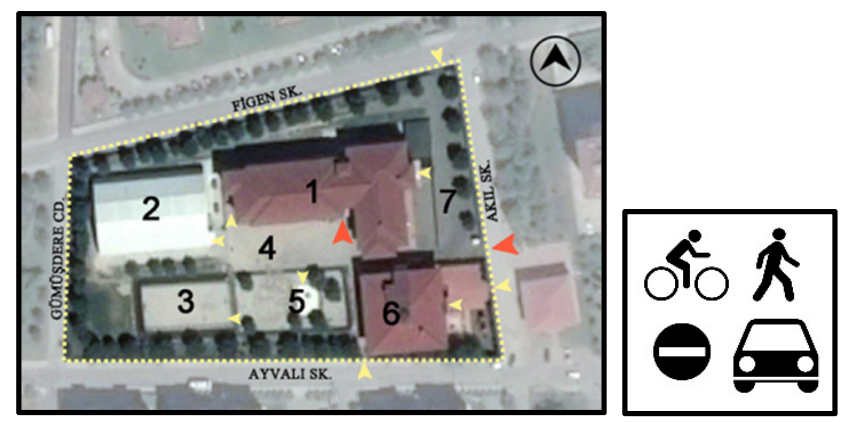

Figure 3: The plan view of Abdurrahman Vardar Primary School.
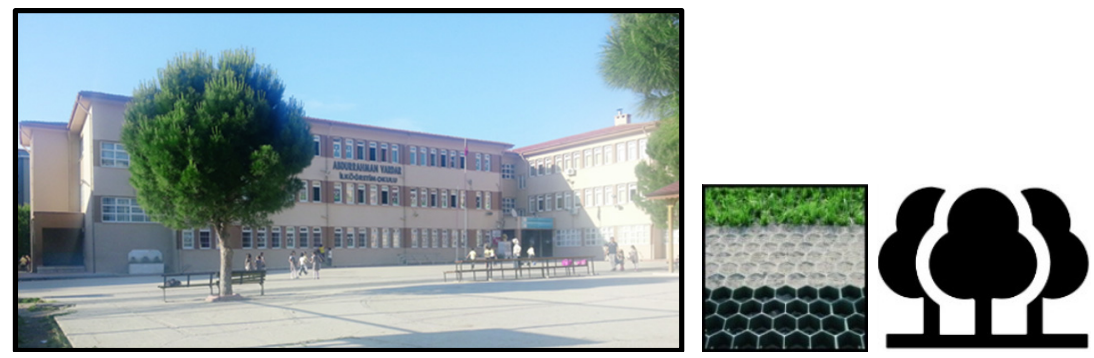

Figure 4: The general view of Abdurrahman Vardar Primary School.

The biggest restriction for the existing buildings is the land use. It is impossible to replace the location of the building. The existing building has been located in east-west direction. Therefore, half of the classrooms face the south, and the rest face the north. Since in most of the education period takes place in winter when the sun light gets into the classrooms with an oblique angel, additional heating is required for the classrooms facing the north and sunlight control for those facing the south. For the administrative department, sunlight control is required for the west sun [16] (Figure 5). 


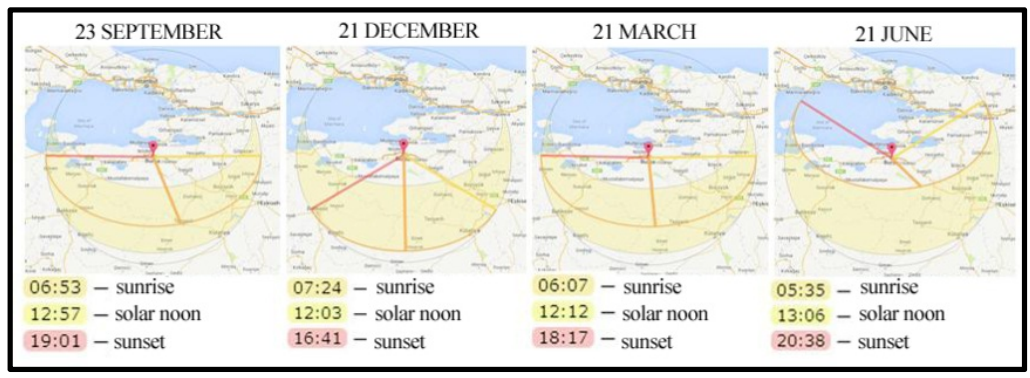

Figure 5: Insolation of Bursa throughout year at 12 o'clock.

\subsection{Energy}

The most energy-consuming stage in the existing buildings is the use stage. It's because, the consumption of energy is too much at this stage.

Since it is impossible to replace the location of the building, additional measurements for solar heating and natural light should be taken after construction or using stage. These measurements may include implementations such as changing the size of windows at the facade, installing solar panels, sun shelves etc. [17] (Figure 6).
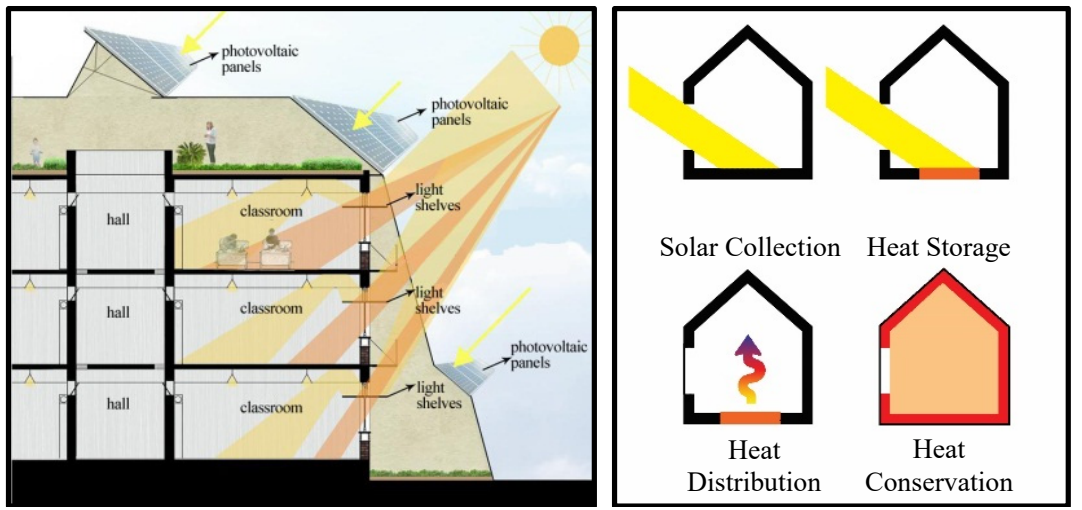

Figure 6: Lighting with passive and active systems in the existing school building.

In the building a second permeable layer of frontage with solar panels was applied as a structure system. By covering the roof, this frontage has also functioned as a different playground for the students. In winter time, the cold air coming from outside is heated through passing it underground and then the air which is struck between two frontages is heated more and then transferred inside the building. By means of the culverts in the walls, natural circulation is created and the rising air is released outside through the roof. In the summer time, the classrooms are cooled by means of circulation of the cool air but, this passive system needs to be supported by HVAC units to some extend and used when needed (Figure 7). 


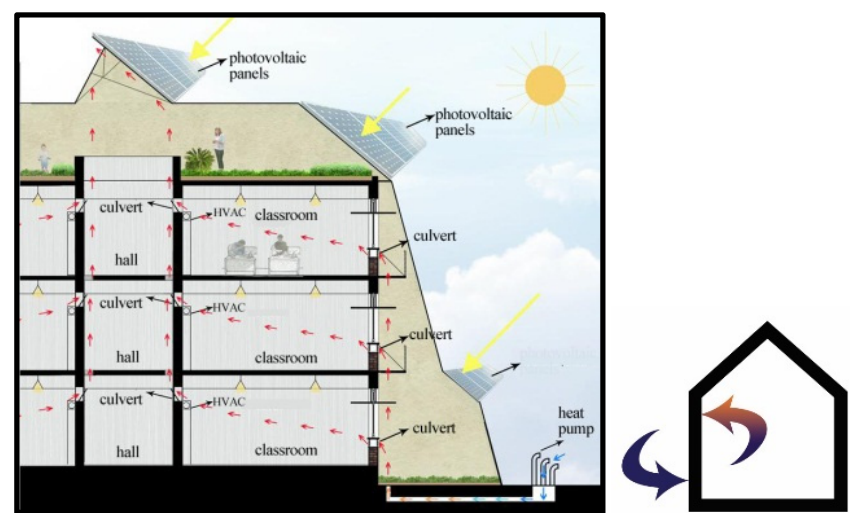

Figure 7: Heating, cooling, and air-conditioning by means of passive and active systems in the existing primary school.

\subsection{Water}

While the students are in primary school, they find out frugal spend. However, leaking taps and reservoirs cause serious water loss. To prevent this, students must be educated on this issue. Besides, low-flow and pressured taps, two-stage syphons should be utilized to reduce the amount of water wasted. Another useful advice is using taps and syphons with photocell.

Rain water is collected, filtered and reused for daily use and watering. Besides, grey waste water gathered from hand washing and shower is recycled and reused in toilet. For water recycling, it is required to change the old instalment and integrate it with a water tank, a filter, and a mechanism for collecting rain water (Figure 8).
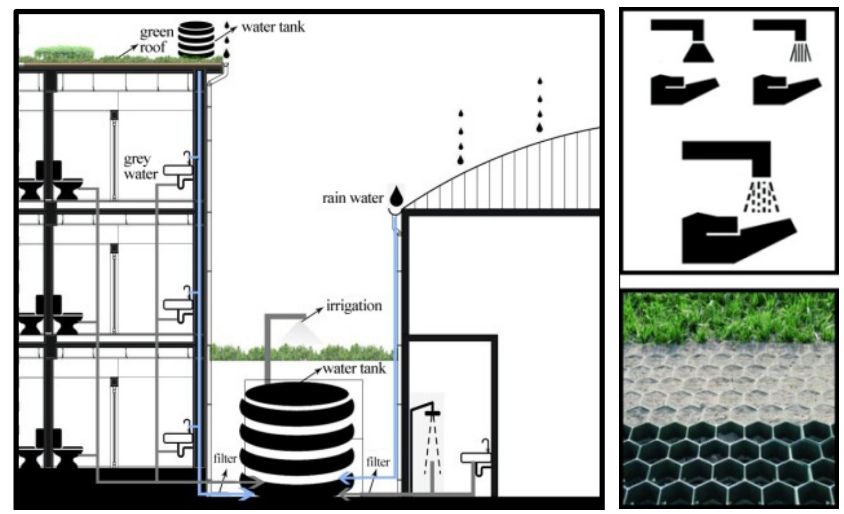

Figure 8: Rain water collecting and waste water recycling concept. 


\subsection{Material}

Sustainable changes of primary schools, it is important to choose suitable material for quality of interior and exterior. Especially, material without carbon emission should be used exterior. Regarding interior materials, it is necessary to consider four main points; thermal comfort, visual comfort, the acoustic comfort and indoor air quality.

\section{Conclusions}

Within the scope of this study, sustainable implementations are dealt with within the framework of physical factors. By working on an existing primary school building, sustainable change has been put forward in terms of structural, technological, environmental, and ecological aspects. Physical dimension of sustainability, which is closely related to architecture, has been argued along with the integration of energy, heating, water conserving with the already existing building. Probable difficulties caused by integration and compatibility of the systems have been pointed out. In order for already existing primary school buildings be evaluated thoroughly, all factors, namely psychological, perceptual, ideological, cultural, social, historical, geographical, political, economic, governmental, socio-economic, legislative, should be evaluated holistically. Socio-economic infrastructure is to be prepared for sustainable practices to be realized physically.

Sustainable changes of primary schools, which have important place among public buildings in Turkey, should be done by interdisciplinary studies, local initiatives, and legislative regulations as soon as possible. This way, existing resources can be conserved and time is saved efficiently. Besides, our country's economic growth can be maintained by saving the amount of resources consumed at the stage of use where most of the energy consumption is spent in buildings. These savings can be used for future investments in education and meet the demands of the schools in need. By means of technological systems, expenses for the bills can be detected and the amount of saving can be measured monthly. A state-funded method could be developed and the state could support the school depending on the saving it makes. Moreover, awareness of sustainability can be raised for future generations. Sustainability goals of individuals and families can be determined. It is aimed that through this approach, sustainable changes of all the state buildings from local primary schools to other buildings even residential ones in Turkey can be achieved.

\section{References}

[1] Gelfand, L. \& Freed, E.C., An introduction to sustainable schools (Chapter 1). Sustainable School Architecture, eds. L. Gelfand \& E.C. Freed, Wiley: New Jersey and Canada, pp. 1-18, 2010.

[2] Gölemen, S., Mevcut Illköğretim Binalarında Sürdürülebilirlik Olanaklarının Araşstırılması, Uludağ University: Bursa, pp. 1-175, 2014. 
[3] Hoşkara, E. \& Sey, Y., Ülkesel koşullar bağlamında sürdürülebilir yapım. İstanbul Technical University Journal, 7(1), pp. 50-61, 2008.

[4] Kim, J.J. \& Rigdon, B., (eds). Sustainable Architecture Module: Introduction to Sustainable Design, National Pollution Prevention Center Publication: Michigan, 1998.

[5] Kibert, C.J., Establishing principles and a model for sustainable construction. Proc. of the $1^{\text {st }}$ Int. Conf. on of CIB TG 16 on Sustainable Construction, University of Florida, Florida, pp. 1-15, 1994.

[6] Sev, A., Sürdürülebilir Mimarlik. Yem: İstanbul, pp. 13-81, 2009.

[7] ÇEDBIK, http://www.cedbik.org/

[8] Canbay Türkyılmaz, Ç., Düzgün, H. \& Canbay, N., Green retrofitting and certification system for existing building. International Ecological Architecture and Planning Symposium, eds. N. Kalamak \& M. Uçak, Chamber of Architecture of Turkey Antalya Branch Publications 14/3: Antalya, pp. 104-115, 2011.

[9] Kayıhan, K. Sürdürülebilir mimarlı̆̆ın yarı nemli Marmara ikliminde tasarlanacak temel eğitim binalarında irdelenmesi ve bir yöntem önerisi. Gebze High-tech Institute: p. 1, Gebze, 2006.

[10] İÇIŞLERİ AFAD, http://www.icisleriafad.gov.tr/lkemizin-deprem-riskiharitasi

[11] Akbulut, T., Sürdürülebilir Temel Eğitim Okul Binaları Tasarımında Deprem Faktörü (Chapter 3), Ilıman-Nemli İklim Kuşăğ İçin Sürdürülebilir Temel Ĕgitim Binalarının Tasarım Kriteleri, ed. S. Tönük, Yıldız Technical Universitiy Publishing: İstanbul, pp. 44-66, 2011.

[12] Smith, P.F., Eco-Refurbishment, Elsevier: Amsterdam, pp. 68-71, 2004.

[13] Roaf, S., Fuentes, M. \& Thomas-Rees, S., Ecohouse. Routledge Publishing: London and New York, pp. 220-241, 2013.

[14] Turkish Statistical Institute (TUIK). The number of Primary School in Turkey in 2015, Turkey, http://www.turkstat.gov.tr/Start.do

[15] Köse, Ç. \& Barkul, Ö., A Study on The Problems of the Implementation of Project Type Primary Structures. Megaron Journal, 7(2), pp. 94-102, 2012.

[16] SUNCAL, www.suncal.net

[17] Tönük, S., Ilıman iklim kuşağı için sürdürülebilir temel eğitim binalarının tasarım kriterleri, Yıldız Technical University Publishing: İstanbul, pp. 1132, 2011. 